\title{
Oral Precancerous Lesions in Childhood: Attention to the Pediatricians and Pediatric Dentists
}

\author{
Çocuklarda Oral Prekanseröz Lezyonlar: Pediatrist ve \\ Pedodontistlerin Dikkatine
}

\author{
(1) Şaziye Sarı ${ }^{1}$, (1) Illhan Kaya ${ }^{2}$, (1) Akif Demirel ${ }^{1}$ \\ ${ }^{1}$ Ankara University Faculty of Dentistry, Department of Pediatric Dentistry, Ankara, Turkey \\ ${ }^{2}$ Uşak University Faculty of Dentistry, Department of Oral and Maxillofacial Surgery, Uşak, Turkey
}

Keywords

Precancerous lesion, oral cancer, oral lichen planus, leukoplakia, erythroplakia

Anahtar Kelimeler

Prekanseröz lezyon, ağız kanseri, oral liken planus, lökoplaki, eritroplaki

Received/Geliş Tarihi : 01.07.2018

Accepted/Kabul Tarihi : 05.11.2018

doi:10.4274/meandros.galenos.2018.95914

Address for Correspondence/Yazışma Adresi: Akif Demirel DDS,

Ankara University Faculty of Dentistry, Department of Pediatric Dentistry, Ankara, Turkey

Phone : +90 5062873380

E-mail : akifdemirel@ankara.edu.tr

ORCID ID: orcid.org/0000-0002-1433-0452

(C) Meandros Medical and Dental Journal, Published by Galenos Publishing House.

This is article distributed under the terms of the Creative Commons Attribution NonCommercial 4.0

International Licence (CC BY-NC 4.0).

\begin{abstract}
Precancerous lesions of oral mucosa, known as premalignant disorders, have greater malignant transform risk concerning dysplastic changes, carcinoma in situ or oral cancers. Oral lichen planus, oral leukoplakia, oral erythroplakia, oral submucous fibrosis, dyskeratosis congenita and epidermolysis bullosa are the most common precancerous lesions in varying frequency in children. Although the etiological factors of these lesions are not entirely understood; the main factors are smoking, alcohol consumption or addictive habits such as areca nut chewing. Moreover; these harmful habits are increasing dramatically in children in early ages and it is challenging regarding public health. Despite the oral cancers or precancerous lesions are rarely seen in childhood, early diagnosis and treatment of these lesions are critical regarding differences in treatment procedures in children, elimination of harmful habits that may cause these lesions and providing regular follow-ups. Therefore, it is thought that specialist in different disciplines which involved pediatric patients need to be informed and raised awareness. The aim of this review is to summarize the clinical features, pathogenesis, etiological factors, current treatment approaches and preventive procedures of the most common oral precancerous lesions in pediatric patients.
\end{abstract}

Öz

Premalign hastalıklar olarak da bilinen oral mukozanın prekanseröz lezyonları; displastik değişimler, karsinoma in-situ ya da oral kanserler konusunda ciddi malign dönüşüm riskine sahiptir. Oral liken planus, oral lökoplaki, oral eritroplaki, oral submüköz fibrozis, diskeratosis kongenita ve epidermolizis büllosa çocuklarda değişken görülme sıklığı ile beraber, en çok görülen prekanseröz lezyonlardır. Bu lezyonların etiyolojik faktörleri tam olarak anlaşılamamış olsa da; ana faktörler sigara kullanımı, alkol tüketimi ya da areca nut çiğneme gibi bağımlılık yapan alışkanlıklardır. Dahası; bu zararlı alışkanlıklar çocuklarda özellikle erken yaşlarda dramatik olarak artmakta ve halk sağlığı konusunda sorun olmaktadır. Çocukluk çağında oral kanserlere ya da prekanseröz lezyonlara nadiren rastlanmasına rağmen, bu lezyonların erken tanı ve tedavisi; çocuklarda tedavi prosedürlerindeki farklılıklar, bu lezyonlara neden olabilecek zararlı alışkanlıkların giderilmesi 
ve düzenli takiplerin sağlanması açısından önemlidir. Bu nedenle, pediyatrik hastaları konu alan farklı disiplinlerdeki uzmanların bilgilendirilmesi ve farkındalığının artırılması gerektiği düşünülmektedir.

Bu derlemenin amacı, pediyatrik hastalarda yaygın görülen oral prekanseröz lezyonların klinik özelliklerini, patogenezini, etiyolojik faktörlerini, güncel tedavi yaklaşımlarını ve önleyici prosedürlerini özetlemektir.

\section{Introduction}

Oral cancers have become an important and growing problem in many parts of the world. Oral and pharyngeal cancers are the sixth most common lesions all over the globe $(1,2)$. In some cases, oral cancers derive from precancerous lesions which can be detectable clinically. The most frequently observed precancerous lesions are; leukoplakia, erythroplakia, oral submucous fibrosis, which have higher potential for malignancy risk (2).

Squamous cell carcinomas (SCCs), one of the most common types of oral cancers, often develop from precancerous lesions. Despite the current developments in the treatment procedures of SCCs, 5 -year survival rate is only about approximately $50 \%$ due to the late diagnosis of SCCs and precancerous lesions. Early diagnosis of precancerous conditions will not only increase the success rate, but also will significantly reduce mortality and morbidity (3).

Although oral cancers are usually seen in the middle and upper age group, younger patient populations have been reported to be affected in recent years (46). Despite the oral cancers are increased in children and adolescents, most of the oral cancer cases have reported without any risk factors in younger patients (7). Therefore, because of the high mortality rate of oral cancers, early diagnosis should not been overlooked, especially in children. The ulcerations, leukoplakia, erytroplakia, swelling and high-risk areas (especially tongue and floor of the mouth) in the oral cavity should be carefully examined and evaluated. In this regard, diagnosis of premalignant lesions is at least as important as diagnosis of oral cancers. Additionally, because the frequency of precancerous lesions is rare in pediatric patients, there are not many prevalence studies in the literature, except for a few case reports.

The main etiological factors of oral cancers and premalignant lesions are use of tobacco products, addictive harmful substances and alcohol consumption. Epidemiological studies have reported that the risk of oral cancers is 5 times higher in smokers than in non-smokers. In addition, even in the cases of treated oral cancer, the risk of occuring and developing secondary malignancy increases when smoking is continued. Likewise, alcohol consumption increases the risk 3-9 times $(8,9)$.

Oral precancerous lesions, risk of future malign changes and their clinic sequelae lead to severe impairments in quality of life and treatment procedures are costly for especially developing countries. Primary prevention of precancerous lesions is possible by eliminating risk factors which will reduce the incidence of premalignant lesions. Unfortunately, informing general public regarding etiological risk factors, prevention and potential complications of precancerous lesions remains inadequate. Hence, early diagnosis is essential to increase treatment success and survival rates (2). In this respect, since pediatricians, pediatric dentists and oral maxillofacial surgeons may be the first physician in diagnosing oral precancerous lesions, they should be informed about these lesions.

The prevalence of smoking, alcohol comsumption and other addictional habits are increasing all over the globe $(10,11)$. Smoking causes deaths worldwide, especially in developing countries (12). Moreover, dependence of tobacco products increases in children and adolescents and emerges as a major threat in populations (12-14). In a study conducted in primary school children in Turkey (15), it has been reported the mean initiation age of smoking was 11.7 and smoking abuse occured mostly due to curiosity and imitation. In another study conducted in Turkey (14), it was reported that $43 \%$ of children in the study group of smoking in any way, while $24 \%$ of regular smokers. In the same study, it was stated that most of the smoker children (86\%) had no difficulty in providing tobacco products and the smoking age was 8.3-10.5 in males and females, respectively. Starting smoking at an early age is also closely related to other risky behaviors such as substance and alcohol use (16). Alcohol use and addiction in children and adolescents remains a significant problem (17). As a matter of fact, studies have proved that alcohol use is started at a 
much earlier age (18). MacKintosh et al. (19) reported that $48 \%$ of children between the ages of $12-13$ had alcohol consumption. Regular use of alcohol products among children is reported $24 \%$ in Turkish population (20). The fact that both smoking and alcohol use are the etiological factors of oral precancerous lesions (8) and the reducing age of these habits in developing countries show that children are at severe risk. On the other hand, it is observed that substance addiction such as areca nut which is etiological factors of precancerous lesions of oral mucosa, especially in Asian societies, increases in children aged 5-12 years (21). The reduce of age of initiation of these harmful habits in children leads to the occurance of potential oral precancerous lesions. Thus, carefully examination of oral precancerous lesions by medical doctors, pediatricians, pediatric dentists and oral maxillofacial surgeons and early treatment in case of diagnosis is life saving.

The aim of this review is to present the clinical aspects and appereances, pathogenesis, etiological factors, current treatment approaches and preventive procedures of the most frequently observed oral precancerous lesions in children

\section{Oral Lichen Planus}

Oral lichen planus (OLP) is one of the chronic inflammatory diseases of oral mucosal membranes. Although OLP is commonly seen in adults, it can be rarely observed in pediatric patients (22-24). In OLP examination in the oral cavity, lesions are generally located bilaterally and symmetrically. OLP lesions are most seen in buccal mucosa, gingiva and dorsum of tongue. On the other hand, clinical appereance of OLP lesions can often seen in the forms of reticular, papular, plaque-like, atrophic, erosive or bullous $(24,25)$. In erosive and atrophic form of OLP, patients complain burning sensation in the mouth $(24,26)$. OLP lesions are mostly diagnosed by clinical and histopathological examination. The lesions are histopathologically characterized by hyperkeratinized epithelium, atrophic epithelium with shortened retepegs (saw tooth), and band-like lymphocytic infiltration in epithelial and connective tissue junction $(27,28)$.

The etiology of OLP is multifactorial; autoimmunity, stress, genetic factors (human leukocyte antigen antigen), systemic diseases, viruses [Helicobacter pylori, Epstein-Barr, Human Papilloma virus (HPV),
Hepatitis C virus], dental restorative materials and some drugs are considered that trigger this disease. $(24,29)$. In etiopathogenesis of the disease, there is an autoimmune reaction in which autocytotoxic CD8+ $T$ cells induce apoptosis of basal cells of the oral epithelium (30). On the other hand, OLP may also be associated with other autoimmune diseases such as Lupus Erythematosus, Pemphigus, Sjögren's syndrome (23).

In children, OLP is more prevalent than some precancerous lesions such as leukoplakia and erythroplakia. OLP seen in children is generally asymptomatic or minimally symptomatic (31). However, in the case reports presented, clinical findings such as bilateral white lineations in the buccal mucosa, white discoloration under the tongue and burning sensation were reported $(23,32)$. OLP, is seen in the form of reticular pattern in many children patients and does not require active treatment. Treatment applications are recommended when the lesions are symptomatic, erosive or ulcerative (31). Local regimens are usually applied to prevent side effects of systemic treatment in children. Hereof, the agents such as topical steroids, topical anesthetics, and topical tacrolimus are used. On the other hand, $0.12 \%$ chlorhexidine irrigation is recommended for plaque control and prevention of Candidiasis lesions. In children with OLP, if the symptoms are severe topical steroids should be combined with systemic steroids $(0.5-1 \mathrm{mg} / \mathrm{kg})$ for 3-6 weeks. In addition, for OLP treatment in children; medications and methods such as retinoids, cyclosporine irrigations, psoralen and ultraviolet therapy, dapson and cryotherapy have also been reported $(24,33)$.

One of the most controversial points related to OLP is whether these lesions are precancerous. The World Health Organization has categorized OLP as a precancerous condition, although there are disagreements between authors in this respect (34). Malathi and Thappa (31) reported that erosive form of OLP usually has a malignant transformation risk in children. Although ulcerative form is known to have malignant tendency in adults, no cases have been reported in children up to the present (35). In case of malignancy, biopsy should be performed on suspicious lesions and cases should be followed at periodic intervals. 
Elimination of the etiological factors such as anxiety and depression, mechanical trauma, dental treatment procedures, harmful oral habits, excessive consumption of spicy foods and irritation of the dental plaque is recommended in prevention of development of OLP and in treatment process in children (31).

\section{Oral Leukoplakia}

Oral leukoplakia (OL) is the most common premalignant lesion of oral mucosa and it was first described by the World Health Organization in 1978 as "a white patch or plaque that cannot be characterized clinically or pathologically as any other disease" $(36,37)$. In 1994, Uppsala, Sweden, it has been reported that this lesion, which is not associated with any physical or chemical cause other than smoking, is highly likely to become an oral cancer (37). OL generally involves all intraoral regions, but common sites of involvement include the dorsum and lateral areas of tongue. The tongue and floor of the mouth, are considered as high-risk zones because these areas exhibit dysplastic transformation for SCC formation (38), however; although the tongue and oral cavity are dangeorus zones for malign transformation, it may vary and all the suspicious cases should be monitored carefully regarding oral cancer (36).

Smoking and use of tobacco products are shown in the etiology of OL, however, malignancy potential may vary with the severity of these habits. Even though it has been suggested that HPV is also considered in the etiology of the disease, there are conflicting results in the literature $(36,37)$. It has also been reported that in addition to mentioned etiologic factors alcohol consumption, chronic irritation, trauma and oral candidiasis may be causative factors of OL (39).

$\mathrm{OL}$ is generally divided into 2 main groups as homogeneous and non-homogeneous. While homogeneous $\mathrm{OL}$ is in the form of thin white flat layer on the mucosal membranes, non-homogeneous type of OL lesions may be seen as speckled, nodular or verrucous form. The speckled type may be whitered clinical appearance and verrucous type of OL lesions may be elevated, proliferative or corrugated clinical appearance (40). It has been reported that the proliferative form is generally more aggressive, malignant and recurrent than the others (41). Clinical and histopathological examination is required in accurate diagnosis of OL lesions as in OLP. One of the most important criteria for histopathological appearance of OL is "epithelial dysplasia". van der Waal et al. (36) reported that epithelial dysplasia is the most critical factor for malignant potential of $\mathrm{OL}$, but emphasizes that lesions without epithelial dysplasia may become malignant. Therefore, all OL patients should be carefully monitored for the risk of oral cancer. Treatment options for $\mathrm{OL}$ include chemotherapeutic agents (vitamins A, C, E), fenretinide, carotenoids, bleomycin, protease inhibitors and antiinflammatory drugs and elimination of risk factors. In addition, conventional excisions, cryosurgery and laser applications are the main surgical approaches for $\mathrm{OL}$ (42).

The incidence of classical $\mathrm{OL}$ in pediatric population is very rare, however in children with HIV+, hairy leukoplakia (HL), a form of leukoplakia, is found at high rates (43-45). The etiological factor of $\mathrm{HL}$ is known as Epstein-Barr virus and in clinical examination, $\mathrm{HL}$ lesions show flat, corrugated or hairy appearance and are located on the lateral or ventral surfaces of the tongue (45). HL lesions are not only seen in HIV+ children but also in other immunosuppression cases. These include leukemia and organ transplantation cases $(46,47)$. In children with $\mathrm{HL}$, treatment is usually provided by the elimination of the predisposing pathologies (48). In addition, although the $\mathrm{OL}$ is not common in children, dyskeratosis congenita (DC) associated $\mathrm{OL}$ is more prevalent in children. $\mathrm{OL}$ is the most primary oral findings of DC. OL in DC patients should be carefully examined and early treatment options should be performed. In this manner, the presence of $\mathrm{OL}$ findings may be beneficial to the clinician in DC diagnosis.

\section{Oral Erythroplakia}

Oral erythroplakia (OE) is defined as "a fiery red patch that cannot be characterized clinically or pathologically as any other disease". OE lesions are well-defined, clinical appereance shows irregular in outline, bright red velvety surface and sometimes granular (49). The red color of the OE lesions is due to the appearance of the underlying microvascular area of the epithelium. Heavy alcohol consumption and smoking are the main etiological factors of OE (50). The most common location of $\mathrm{OE}$ is soft palate and accurate differential diagnosis should be made with other erythematous oral lesions by histopathological examination (49-51). In this manner, as with the other lesions, OE lesions should be diagnosed by clinical and 
histopathological examination. Histopathologically, epithelium of oral mucosa is mostly atrophic, nonkeratinized and sometimes hyperplastic. Biopsy and surgical excision are recommended in surgical treatment of OE $(52,53)$. In some cases, OE can be seen with OL, grouped together, and it is termed erythroleukoplakia. The most common sites of involvement include floor of the mouth, soft palate, ventral surface of the tongue and tonsillas. Although this lesion is usually asymptomatic, sometimes patients may complain of burning sensation or pain (50). OE is rarely seen in children (54), nevertheless child patients should be carefully assessed and followed regarding the formation of these lesions and high malignancy risk (7). Otherwise, lesion showing rapid dysplastic formation is at risk of carcinoma in situ or invasive carcinoma (49-51).

\section{Oral Submucous Fibrosis}

Oral submucous fibrosis (OSF); is a premalignant oral mucosa lesion characterized by chronic inflammation and progressive fibrosis of the oral submucosal tissues including lamina propria and deeper connective tissues. The main findings of OSF are marked rigidity in oral tissues, leathery mucosal texture, loss of fibroelasticity and severe limitation of mouth opening $(55,56)$. It has been reported that the OSF may even affect the pharynx in some cases in the oral region (56). Clinical examination of OSF reveals white discoloration of oral mucosa, pigmentation or loss of papilla, sunken cheeks and limited mobility, horizontal bands along the soft palate, deformation in the uvula and mucosal burning sensation $(49,57)$. However, it is stated that the clinical findings in OSF are quite variable and the severity of disease can be measured by the limitation of mouth opening (49).

Areca nut chewing are the dominant factor in OSF etiology and it is used as fourth harmful habit in the world after tobacco, alcohol and cafein (58). The use of Areca nut is widely preferred, especially in India, Western Pacific, South and Southeast Asia $(21,59)$. The sale of Areca nut products in attractive and coloured packages in general public areas in recent years has lead to an increase prevalence of OSF in young populations. The addiction of areca nut and the increased risk of OSF especially in children aged 5-12 cause great concerns (21). Gupta et al. (21), in a case study of two children aged 10 and 11 years, reported that children were chewing areca nut for 6-7 years and main clinical findings were limitation of mouth opening, burning oral mucosa and poor oral hygiene.

In case of OSF diagnosis; providing regular nutrition, avoidance of spicy foods, maintainance of oral hygiene, mouth opening exercises to increase mouth opening and follow-ups are recommended. Gupta et al. (21) reported that healing could be achieved by providing these proposals. It is stated such harmful habits that are risky in quality of life are generally acquired in childhood and this results in addiction. In this respect, it is recommended that pediatric specialists should be aware of this issue, informed about early diagnosis practices such as detailed clinical examination, biopsy and active preventive approaches (21).

\section{Dyskeratosis Congenita}

DC is a rare hereditary bone marrow failure syndrome and DC patients have increased risk of malignancy and morbidity $(49,60,61)$. DC disease characterized by a triad which include dystrophic nails, reticular skin pigmentation and leukoplakic patches in mucous membranes. Pulmonary fibrosis and liver diseases are also accompanied by the syndrome. DC disease is thought to originate from early telomeric shortening and it is inherited autosomal dominant, autosomal recessive or $\mathrm{X}$-linked genetic pattern (6062).

$\mathrm{OL}$ is a common oral finding in $65-80 \%$ of the patients with DC $(49,62)$. OL is generally seen in the dorsum of tongue and buccal mucosa, similar to classic OL (63). Tongue is affected at a young age and in most cases, especially in children under 15 years of age $(49,64)$. Therefore, OL which seen in DC differs prevalence from classical $\mathrm{OL}$ in children. Ogden et al. (65) reported a 10-year-old patient had OL and all the triad of DC with a high malignant risk. Bongiorno et al. (62) also reported that DC can be transformed to many types of cancer, especially oral SCC in the head and neck region. In addition, oral gingivitis, gingival bleeding, dental caries and periodontitis are seen as oral findings in patients with DC in addition to OL (66). Due to the potential malignancy risk, diagnosis of DC should be provided at an early stage, the treatment process should be initiated and other dental treatments should be completed. Morever, DC should be considered in all cases in which white lesions exists in oral cavity. 


\section{Epidermolysis Bullosa}

Epidermolysis bullosa (EB) is characterized by fragility of the skin and mucous membranes resulting in painful blisters and erosions (67). Intraoral findings such as ulcerations, scarring and microstomias are seen in all subtypes of EB (49). In some subtypes of $E B$, lesions are tended to be transformed into SCCs (68-70). As EB is found in children $(69,71-73)$, early diagnosis is mostly important because of malignancy risk. In addition, it has been reported that in children with EB showed common dental caries and delay of tooth eruption. In childhood, dental treatments must be completed rapidly and the comfort of life should be provided $(69,71,73)$.

Treatment of EB is usually based on vital support and symptoms. Perforation of the blisters accelerates the healing process and prevents the spread of the lesions. However, open wounds should be covered with non-adhesive materials such as sterile gauze or hydrogel (74). In addition, gene and cell therapy, recombinant protein infusions, intradermal injections of allogenic fibroblasts and stem cell transplantation are known as the current treatment options. The developing treatment modalities aim to improve wound healing and better quality of life for EB patients $(71,72,75)$. Above all, as with other precancerous lesion, all EB cases should be detailed examined and monitored since it may be future malign changes.

\section{Conclusion}

The decrease of initiation age of smoking, alcohol consumption and harmful addictional habits increases the risk of occurrence oral precancerous lesions in children especially in developing countries. However, despite these concerns, oral cancers and premalignant lesions are not seen commonly in children. The low prevalence rate of oral precancerous lesions in children compared to adults can be attributed to the need for a certain amount of time for the occurance of destructive effects even if children are started these harmful habits at an early age. Therefore, pediatric patients who having these etiological factors should be monitored and followed up for the risk of development of oral precancerous lesions. These social concerns are the future troubles of the most part of the world and require immediate intervention. In this respect; parents, school teachers, children and adolescents should be carefully informed. On the other hand, the probable complications of the precancerous lesions, decreased the quality of life and high mortality rates are require early diagnosis and treatment. Additionally, early diagnosis, carefully evaluating of the cases, monitoring and periodic follow-ups, evaluating the clinical and histologic status provide lower morbidity and mortality rates. Therefore, extraoral and intraoral examination of the head and neck region in pediatric patients have an important effect in diagnosis of the changes affecting oral mucosa and oral cavity. In this respect, all the findings showing premalignancy in pediatric patients should not be overlooked by medical doctors, pediatric specialists, pediatric dentists or oral and maxillofacial surgeons and multidisciplinary approaches should be provided.

\section{Ethics}

Peer-review: Externally peer-reviewed.

\section{Authorship Contributions}

Concept: Ş.S., I.K., A.D., Design: Ş.S., Data Collection or Processing: Ş.S., I.K., A.D., Analysis or Interpretation: Ş.S., I.K., A.D., Literature Search: Ş.S., I.K., A.D., Writing: Ş.S., I..K., A.D.

Conflict of Interest: No conflict of interest was declared by the authors.

Financial Disclosure: The authors declared that this study received no financial support.

\section{References}

1. Warnakulasuriya S. Global epidemiology of oral and oropharyngeal cancer. Oral Oncol 2009; 45: 309-16.

2. Kumar S, Debnath N, Ismail MB, Kumar A, Kumar A, Badiyani BK, et al. Prevalence and Risk Factors for Oral Potentially Malignant Disorders in Indian Population. Adv Prev Med 2015; 2015: 208519.

3. IraniS. Pre-Cancerous Lesions in the Oral and Maxillofacial Region: A Literature Review with Special Focus on Etiopathogenesis. Iran J Pathol 2016; 11: 303-22.

4. Chen JK, Katz RV, Krutchkoff DJ. Intraoral squamous cell carcinoma. Epidemiologic patterns in Connecticut from 1935 to 1985. Cancer 1990; 66: 1288-96.

5. Llewellyn CD, Johnson NW, Warnakulasuriya KA. Risk factors for squamous cell carcinoma of the oral cavity in young people--a comprehensive literature review. Oral Oncol 2001; 37: 401-18.

6. Schantz SP, Yu GP. Head and neck cancer incidence trends in young Americans, 1973-1997, with a special analysis for tongue cancer. Arch Otolaryngol Head Neck Surg 2002; 128: 268-74.

7. Oliver RJ, Dearing J, Hindle I. Oral cancer in young adults: report of three cases and review of the literature. Br Dent J 2000; 188: $362-5$. 
8. Neville BW, Day TA. Oral cancer and precancerous lesions. CA Cancer J Clin 2002; 52: 195-215.

9. Silverman S Jr, Griffith M. Smoking characteristics of patients with oral carcinoma and the risk for second oral primary carcinoma. J Am Dent Assoc 1972; 85: 637-40.

10. Warren CW, Riley L, Asma S, Eriksen MP, Green L, Blanton C, et al. Tobacco use by youth: a surveillance report from the Global Youth Tobacco Survey project. Bull World Health Organ 2000; 78: 868-76.

11. Bolat F, Eren Ö, Bolat G, Can E, Cömert S, Uslu HS, et al. Maternal smoking during pregnancy and effects on neonatal anthropometry: a prospective study. Turk J Med Sci 2012; 42: 999-1005.

12. Narain R, Sardana S, Gupta S, Sehgal A. Age at initiation \& prevalence of tobacco use among school children in Noida, India: a cross-sectional questionnaire based survey. Indian J Med Res 2011; 133: 300-7.

13. Bilir N. Successes and Challenges in Tobacco Control-Turkish Experience of 20 Years. Eurasian J Pulmonol 2017; 19: 119-23.

14. Konuk S, Coban H, Nalbant A, Bilgin C. Smoking prevalence among elementary school-age children in Sirnak province in Turkey. Biomedical Research 2017; 28: 5054-7.

15. Uncu $Y$, Irgil E, Karadag M. Smoking patterns among primary school students in Turkey. Scientific World Journal 2006; 6: 166773.

16. Taylor-Robinson DC, Wickham S, Campbell M, Robinson J, Pearce A, Barr B. Are social inequalities in early childhood smoking initiation explained by exposure to adult smoking? Findings from the UK Millennium Cohort Study. PLoS One 2017; 12: e0178633.

17. American Academy of Pediatrics: Committee on Substance Abuse. Alcohol use and abuse: a pediatric concern. Pediatrics 2001; 108: 185-9.

18. Nelson CB, Heath AC, Kessler RC. Temporal progression of alcohol dependence symptoms in the U.S. household population: results from the National Comorbidity Survey. J Consult Clin Psychol 1998; 66: 474-83.

19. MacKintosh A, Hastings G, Hughes K, Wheeler C, Watson J, Inglis J. Adolescent drinking: the role of designer drinks. Health Education 1997; 97: 213-24.

20. Erdamar G, Kurupinar A. The habit of drug addiction and prevalence among the secondary school students: sample of Bartin city. Afyon Kocatepe Journal of Social Sciences 2014; 16 : 65-84.

21. Gupta VK, Malhotra S, Patil R, Tripathi A. Oral submucous fibrosis at pediatric age, now time to think: Series of two cases. Indian J Med Paediatr Oncol 2013; 34: 107-10.

22. Patel BP, Rawal UM, Shah PM, Prajapati JA, Rawal RM, Dave TK, et al. Study of tobacco habits and alterations in enzymatic antioxidant system in oral cancer. Oncology 2005; 68: 511-9.

23. Mohan Das U, JP B. Oral lichen planus in children. Int J Clin Pediatr Dent 2009; 2: 49-51.

24. Srinivas K, Aravinda K, Ratnakar P, Nigam N, Gupta S. Oral lichen planus - Review on etiopathogenesis. Natl J Maxillofac Surg 2011; 2: 15-6.
25. Andreasen JO. Oral lichen planus. 1. A clinical evaluation of 115 cases. Oral Surg Oral Med Oral Pathol 1968; 25: 31-42.

26. Brown RS, Bottomley WK, Puente E, Lavigne GJ. A retrospective evaluation of 193 patients with oral lichen planus. J Oral Pathol Med 1993; 22: 69-72.

27. Anees MM, Szepietowski J. Oral lichen planus: A review of aetiopathogenesis, clinical manifestations, histology and treatment modalities. Dermatologia Kliniczna 2007; 9: 243-8.

28. Padmini C, Bai KY, Chaitanya V, Reddy MS. Ulcerative lichen planus in childhood. Case Rep Dent 2013; 2013: 874895.

29. Gupta S, Jawanda MK. Oral Lichen Planus: An Update on Etiology, Pathogenesis, Clinical Presentation, Diagnosis and Management. Indian J Dermatol 2015; 60: 222-9.

30. Eversole LR. Immunopathogenesis of oral lichen planus and recurrent aphthous stomatitis. Semin Cutan Med Surg 1997; 16 : 284-94.

31. Malathi M, Thappa DM. Management of childhood lichen planus. NJDVL 2014; 12: 1-6.

32. George S, John SA, Anandaraj S, Issac JS, Harris A, Reshmi J. Childhood Oral Lichen Planus: Report of Two Cases. J Dent (Tehran) 2015; 12: 374-8.

33. De Moraes PC, Teixeira RG, Tacchelli DP, Bönecker M, Junqueira $\mathrm{JL}$, Oliveira LB. Atypical case of oral lichen planus in a pediatric patient: clinical presentation and management. Pediatr Dent 2011; 33: 445-7.

34. Shirasuna K. Oral lichen planus: Malignant potential and diagnosis. Oral Science International 2014; 11: 1-7.

35. Pakfetrat A, Javadzadeh-Bolouri A, Basir-Shabestari S, Falaki F. Oral Lichen Planus: a retrospective study of 420 Iranian patients. Med Oral Patol Oral Cir Bucal 2009; 14: E315-8.

36. van der Waal I, Schepman KP, van der Meji EH, Smeele LE. Oral leukoplakia: a clinicopathological review. Oral Oncol 1997; 33: 291-301.

37. Parlatescu I, Gheorghe C, Coculescu E, Tovaru S. Oral leukoplakia - an update. Maedica (Buchar) 2014; 9: 88-93.

38. Sunil A, Kurien J, Mukunda A, Basheer AB, Deepthi. Common Superficial Tongue Lesions. Indian J Clin Practice 2013; 23: 53442.

39. Carnelio S, Rodrigues GS, Shenoy R, Fernandes D. A brief review of common oral premalignant lesions with emphasis on their management and cancer prevention. Indian J Surg 2011; 73: 256-61.

40. Warnakulasuriya S, Johnson NW, van der Waal I. Nomenclature and classification of potentially malignant disorders of the oral mucosa. J Oral Pathol Med 2007; 36: 575-80.

41. van der Waal I, Reichart PA. Oral proliferative verrucous leukoplakia revisited. Oral Oncol 2008; 44: 719-21.

42. Deliverska EG, Petkova M. Management of oral leukoplakia analysis of the literature. J of IMAB 2017; 23: 1495-1504.

43. Ferguson FS, Archard H, Nuovo GJ, Nachman S. Hairy leukoplakia in a child with AIDS--a rare symptom: case report. Pediatr Dent 1993; 15: 280-1.

44. Laskaris G, Laskaris M, Theodoridou M. Oral hairy leukoplakia in a child with AIDS. Oral Surg Oral Med Oral Pathol Oral Radiol Endod 1995; 79: 570-1. 
45. Dias EP, Israel MS, Silva Junior A, Maciel VA, Gagliardi JP, Oliveira $\mathrm{RH}$. Prevalence of oral hairy leukoplakia in 120 pediatric patients infected with HIV-1. Braz Oral Res 2006; 20: 103-7.

46. Cho HH, Kim SH, Seo SH, Jung DS, Ko HC, Kim MB, et al. Oral hairy leukoplakia which occurred as a presenting sign of acute myeloid leukemia in a child. Ann Dermatol 2010; 22: 73-6.

47. Engelhardt K, Siegel J, Das BB. A New White Oral Lesion in a Pediatric Heart Transplant Recipient Following Campath Therapy: Expanding the Differential Diagnosis. J HIV AIDS 2015; 1.

48. Kreuter A, Wieland U. Oral hairy leukoplakia: a clinical indicator of immunosuppression. CMAJ 2011; 183: 932.

49. Warnakulasuriya S. Clinical features and presentation of oral potentially malignant disorders. Oral Surg Oral Med Oral Pathol Oral Radiol 2018; 125: 582-90.

50. Villa A, Villa C, Abati S. Oral cancer and oral erythroplakia: an update and implication for clinicians. Aust Dent J 2011; 56: 2536.

51. Warnakulasuriya S, Reibel J, Bouquot J, Dabelsteen E. Oral epithelial dysplasia classification systems: predictive value, utility, weaknesses and scope for improvement. J Oral Pathol Med 2008; 37: 127-33.

52. Hashibe M, Mathew B, Kuruvilla B, Thomas G, Sankaranarayanan $\mathrm{R}$, Parkin DM, et al. Chewing tobacco, alcohol, and the risk of erythroplakia. Cancer Epidemiol Biomarkers Prev 2000; 9: 63945.

53. Reichart PA, Philipsen HP. Oral erythroplakia--a review. Oral Oncol 2005; 41: 551-61.

54. Greer RO, Said S. Oral Epithelial Neoplasms. In: Greer RO, Marx RE, Said S, Prok LD, editors. Pediatric Head and Neck Pathology. Cambridge University Press 2017: 128-41.

55. Kerr AR, Warnakulasuriya $S$, Mighell AJ, Dietrich T, Nasser M, Rimal J, et al. A systematic review of medical interventions for oral submucous fibrosis and future research opportunities. Oral Dis 2011; 17: 42-57.

56. Gupta J, Gupta KK, Samadi FM, Kabiraj A. Smokeless tobacco and oral cancer: A review. Indian J Oral Sci 2012; 3: 74-8.

57. Zain RB, Ikeda N, Gupta PC, Warnakulasuriya S, van Wyk CW, Shrestha $P$, et al. Oral mucosal lesions associated with betel quid, areca nut and tobacco chewing habits: consensus from a workshop held in Kuala Lumpur, Malaysia, November 25-27, 1996. J Oral Pathol Med 1999; 28: 1-4.

58. Sullivan RJ, Hagen EH. Psychotropic substance-seeking: evolutionary pathology or adaptation? Addiction 2002; 97: 389400.

59. Shah SM, Merchant AT, Lucy SP, Chotani RA. Addicted schoolchildren: prevalence and characteristics of areca nut chewers among primary school children in Karachi, Pakistan. J Paediatr Child Health 2002; 38: 507-10.
60. Ray JG, Swain N, Ghosh R, Richa, Pattanayak (Mohanty) S. Dyskeratosis congenita with malignant transformation. BMJ Case Rep 2011; 2011.

61. Fernández García MS, Teruya-Feldstein J. The diagnosis and treatment of dyskeratosis congenita: a review. J Blood Med 2014; 5: 157-67.

62. Bongiorno M, Rivard S, Hammer D, Kentosh J. Malignant transformation of oral leukoplakia in a patient with dyskeratosis congenita. Oral Surg Oral Med Oral Pathol Oral Radiol 2017; 124 : e239-42.

63. Handley TP, Ogden GR. Dyskeratosis congenita: oral hyperkeratosis in association with lichenoid reaction. J Oral Pathol Med 2006; 35: 508-12.

64. Noto Z, Tomihara K, Furukawa K, Noguchi M. Dyskeratosis congenita associated with leukoplakia of the tongue. Int J Oral Maxillofac Surg 2016; 45: 760-3.

65. Ogden GR, Connor E, Chisholm DM. Dyskeratosis congenita: report of a case and review of the literature. Oral Surg Oral Med Oral Pathol 1988; 65: 586-91.

66. Üçok Ö, Özen T, Karakurumer K, Köse O, Süer BT. Dyskeratosis Congenita: Report of a New Caseand Review of the Turkish Literature. Turkiye Klinikleri J Dental Sci 2003; 9: 93-7.

67. Salavastru CM, Sprecher E, Panduru M, Bauer J, Solovan CS, Patrascu V, et al. Recommended strategies for epidermolysis bullosa management in romania. Maedica (Buchar) 2013; 8: 200-5.

68. Wright JT. Oral manifestations in the epidermolysis bullosa spectrum. Dermatol Clin 2010; 28: 159-64.

69. Eswara U. Dystrophic epidermolysis bullosa in a child. Contemp Clin Dent 2012; 3: 90-2.

70. Parushetti AD, Agrawal JM, Nanjannawar LG, Agrawal MS. Oral manifestations of epidermolysis bullosa dystrophica: a rare genetic disease. BMJ Case Rep 2013; 2013.

71. Kummer TR, Nagano HC, Tavares SS, Santos BZ, Miranda C. Oral manifestations and challenges in dental treatment of epidermolysis bullosa dystrophica. J Dent Child (Chic) 2013; 80: 97-100.

72. Scheidt L, Sanabe ME, Diniz MB. Oral Manifestations and Dental Management of Epidermolysis Bullosa Simplex. Int J Clin Pediatr Dent 2015; 8: 239-41.

73. Lindemeyer R, Wadenya R, Maxwell L. Dental and anaesthetic management of children with dystrophic epidermolysis bullosa. Int J Paediatr Dent 2009; 19: 127-34.

74. Torres CP, Gomes-Silva JM, Mellara TS, Carvalho LP, Borsatto MC. Dental care management in a child with recessive dystrophic epidermolysis bullosa. Braz Dent J 2011; 22: 511-6.

75. Dağ C, Bezgin T, Özalp N. Dental management of patients with epidermolysis bullosa. Oral Health Dent Manag 2014; 13: 623-7. 